\title{
The European Union: What Might The Future Hold?
}

Debora J. Gilliard, (Email: gilliard@mscd.edu), Metropolitan State College of Denver

\section{INTRODUCTION}

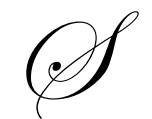

ome extraordinary events have been taking place in the European Union in recent years. This group of countries has introduced a new currency, has expanded to a 25 member country single market, and is in the process of implementing a European Union constitution. Because these events will have an impact on the United States and on global business, it is important to monitor and evaluate activities of the EU. This paper briefly reviews the development of the European Union, then discusses recent events and the implications of European Union activities for business, and looks at future possibilities for the EU.

\section{THE PAST}

\section{History}

In 1952 six countries (Belgium, France, Germany, Italy, Luxembourg, and the Netherlands) joined together to create the European Coal and Steel Community when they signed the Treaty of Paris. The purpose was to create a unified market for coal and steel products, lift restrictions on imports and exports, and to create a unified labor market (EU 2005; Hill, 2004). In 1957, the Treaty of Rome was signed creating the European Community (aka European Economic Community). The Treaty of Rome created the common market and identified key objectives which were: the elimination of internal trade barriers, the free movement of labor and capital, free movement of goods and services through the harmonization of member country laws, and the establishment of common policies in agriculture and transportation. The 5 institutions to govern the European Community were established (Europa, 2005; Hill, 2004):

- $\quad$ The European Parliament - members are elected by the citizens of member countries and it debates and amends legislation.

- $\quad$ Council of the European Union - is composed of the government representatives of the member countries and it resolves policy issues and sets policy direction.

- $\quad$ European Commission - proposes legislation, implements laws, and monitors adherence to laws.

- $\quad$ Court of Justice - ensures compliance with the laws of the European community.

- $\quad$ Court of Auditors - manages the budget of the European community.

The European Monetary System was established in 1979 to stabilize exchange rates among the member countries. The Exchange Rate Mechanism was designed to reduce the amount that currencies of member countries could fluctuate, stimulate trade and investment, and help prevent inflation (Encarta, 2004).

The Single European Act was adopted in 1987 and committed the EC to work toward the development of a single market by 1992. The Act proposed a number of actions to aid in the achievement of the single market: removal of frontier controls, mutual recognition of product standards, open public procurement to non-national suppliers, lift barriers to competition in retail banking and insurance, remove restrictions on foreign exchange transactions, and abolish cabotage (Hill, 2004). 


\section{The European Union}

The Maastricht Treaty of 1991 set the European countries on a road toward full economic and monetary integration. So important was this step that the member countries changed their name from the European Community to the European Union. There are three stages toward economic and monetary union set forth in the Maastricht Treaty. The first stage was the elimination of exchange controls and the flow of capital, which had begun prior to 1991. The second stage, set to start in 1994, was the coordination of member country economies to reduce inflation and budget deficits. The third stage was designed for those countries participating in a single currency. These countries had to meet criteria regarding the size of government budget deficits, interest rate levels, inflation, and currency stability. On January 1, 1999, the euro went into effect in 12 of the 15 European Union countries (Britain, Sweden, and Denmark have opted out of using the euro as their national currency) and coins and currency were issued on January 1, 2002 (Encarta, 2004). There are multiple benefits to having a common currency in the European countries. Benefits include: decreased currency exchange costs and risks to businesses, allow consumers and buyers to compare prices throughout the EU, because of expected increased competition producers will find ways to achieve efficiencies and reduce costs, a more liquid and transparent capital market will lead to lower costs of capital for businesses, and there will be an increased number of investment options for both businesses and individuals. The common currency also has some drawbacks which will include: National government officials will have less control over monetary policy with the establishment of the European Central Bank and its mandate to set monetary policy, there are many different country economies in the EU (including differing wage rates, tax rates, and business cycles) all of which will react differently to economic conditions, and critics believe a political union to set common policies should have been established prior to the introduction of an economic union and a single currency (Hill, 2004).

The European Union member countries work together for peace and prosperity. One objective is to speak as one voice and have a unified position on world issues (Encarta, 2004; Europa, 2005). In the beginning, the EU countries cooperated on issues about trade and the economy. By 2005 the EU is dealing with many other subjects such as citizens' rights, job creation, regional development, and environmental protection (Europa, 2005).

\section{THE PRESENT: 2002-2005}

\section{The Euro}

It was expected that an economic and monetary union would provide greater macroeconomic stability and improve the efficiency in the euro area. After five years, an evaluation of the impact of the euro suggests there has been some success in achieving these objectives. In a report issued by Europa (2005), the goal toward achieving macroeconomic stability has been successful. The economies of the euro countries have achieved a reasonable degree of nominal convergence. Short term interest rates are going down and inflation is at a level that is consistent with the European Central Bank's definition of price stability. However, GDP growth and productivity trends have been disappointing. Overall, the monetary policy of the European Central Bank has created a stable macroeconomic environment.

In an assessment of fiscal policy, results are somewhat mixed. Member countries are expected to keep deficit levels below $3 \%$ of GDP and debt levels blow 60\% of GDP. Overall, deficit levels have risen in member countries, although many small member countries did achieve budget goals. In many cases, member countries did not take an opportunity in times of strong growth to pursue and implement budget reforms. It appears that peer pressure among member countries to conform to policies has resulted in governments taking corrective actions sooner rather than later, especially in the small countries. The report indicates that peer pressure and enforcement mechanisms relating to budget situations have been less effective in larger countries.

It was expected that the introduction of the euro would increase competition and change the behavior of firms. Evidence indicates that the single currency has increased the attractive of foreign investment in the euro area. There has been progress toward the integration of financial markets. Today there is greater access to capital, reduced risk, reduced costs of financing, and increased resilience of financial institutions. However, there are still some barriers (cultural, regulatory, legal, and technical) that will continue to obstruct financial integration. 
The Europa (2005) report suggests that future challenges include: dealing with the causes of slow growth, preparing for the economic and budgetary challenges of an aging population, successfully integrating the 10 new members to the European Union, re-establishing a framework for coordination and enforcement of budgetary policies and goals, and developing a greater role in the international financial and monetary system.

\section{Enlargement}

On May 1, 2004, the European Union expanded its membership to include 10 new countries, for a total membership of 25 countries. The 10 new members are: Cyprus, Czech Republic, Estonia, Hungary, Latvia, Lithuania, Malta, Poland, Slovakia, and Slovenia. The United States and Japan are the two largest markets outside of the EU for EU products and are the largest non-European suppliers (Encarta 2004). Key statistics comparing the EU 25 countries with the U.S. and Japan are shown below.

\section{Key Statistics}

\begin{tabular}{||l|l|l|l||}
\hline & EU 25 & US & Japan \\
\hline Population (2003 millions) & 454.56 & 293.03 & 127.62 \\
\hline Unemployment rate (2003) & $9.1 \%$ & $6.0 \%$ & $5.4 \%$ \\
\hline GDP (2003, USD billions) & 11,017 & 11,000 & 4,301 \\
\hline GDP per capita (2003) & $\$ 24,027$ & $\$ 37,756$ & $\$ 33,720$ \\
\hline Inflation (2003) & $2.0 \%$ & $1.6 \%$ & $-0.2 \%$ \\
\hline Total Imports (2003 USD billions) & 1,047 & 1,517 & 477 \\
\hline Total Exports (2003 USD billions) & 1,250 & 1,021 & 597 \\
\hline World Import Share & $14.0 \%$ & $22.9 \%$ & $6.8 \%$ \\
\hline World Export Share & $13.1 \%$ & $8.5 \%$ \\
\hline
\end{tabular}

Source: (European Union, 2005)

As can be seen, the EU 25 presents a formidable trading power and will have a greater influence in the world economy and will experience greater influence in the world political environment as a result of enlargement (Batterson, 2004).

In order to be considered as a member of the EU, the 10 new countries had to fulfill conditions of membership which included democracy, the rule of law, a functioning market economy, and the ability to take on member obligations (European Union, 2005). Since 2000, the EU has contributed over 3 billion euros each year to the 10 countries to aid them in their preparation for membership in the EU. The 10 new members will receive 10 billion euro per year for the next 3 years in financial support to further their development (Batterson, 2004).

Positive and negative effects of the enlargement of the EU will be felt not only in the European Union, but throughout the world. A single set of rules and a single tariff allows goods that have cleared customs in one of the 25 member states to move freely throughout the EU. External tariffs in the new member states have decreased from an average of $9 \%$ to an average of $4 \%$ which decreases the costs of goods from countries such as the United States. A single set of trade rules for business among the new member countries allows businesses and investors to benefits from regulatory standards especially in the areas of intellectual property rights, government procurement, and competition. There is free movement of capital between member countries and third countries and a more favorable investment environment has been created (European Union, 2004). As a result it is easier for businesses to obtain capital and at a lower cost (Ambler, et. al., 2000). Non-EU service providers receive the same treatment in the new member countries as they receive in the original $15 \mathrm{EU}$ countries. EU research programs are open to international participants (European Union 2004) although the OECD (2004) has noted that there is a gap in the innovation and diffusion of new technology between the EU countries and the best performing OECD countries. Therefore, the OECD suggests that there be a greater investment in higher education, encouragement of business creation (one way to do this is to change bankruptcy laws), and encouragement of private funding of R\&D. 
The enlarged EU will create a more competitive business environment (Ambler, et. al. 2000). Northern Ireland has already experienced the effects in the textile and clothing industries of lower labor costs that are available in the 10 new member countries as companies. Irish food processors are experiencing increased competition for export markets and are finding it more difficult to maintain their share of the UK supermarket business (McGill, 2004). On the other hand, companies in the hi-tech industries and those that manufacture medical and optical instruments will benefit from enlargement with new market opportunities (McGill 2004).

International firms conducting business in the EU-25 will realize numerous benefits. The larger single market brings greater opportunities for companies to achieve economies of scale, to reconfigure supply chains to take advantage of economies of scale and lower costs of inputs, and the common standards allow new products to be introduced at lower costs (Ambler, et. al, 2000).

Although the enlarged EU allows for free movement of labor among member countries, there are obstacles to be overcome. Language barriers do exist and decreases the mobility of labor. There are wage differentials between immigrants and nationals and often qualifications of labor are not recognized in other EU countries. Workers from new members are not necessarily free to seek work in other EU countries because many of the EU 15 countries have introduced transitional arrangements to decrease the flow of immigrants from the new members because they are concerned about the increased social costs that may occur, especially in the areas of education and healthcare. For example, the Netherlands and Portugal have imposed a quota while Ireland, Sweden, and the United Kingdom have not imposed any transitional arrangements (OECD, 2004). To ease some of these problems the OECD (2004) suggests that: wages should be more responsive to local conditions, employment legislation should be reformed, changes should be made to the benefit systems to provide incentives to search for a job, and improvements should be made regarding the portability of occupational pensions.

\section{EU Constitution}

At a meeting in Laeken in December 2001, the European Council announced that it had opted for the creation of a Convention to bring about reform. The European Convention, which first met February 28, 2002 and completed its work July 18, 2003, submitted a draft treaty establishing a Constitution for Europe. The constitution is a single document that replaces all Treaties accumulated over the past 50 years. The major parts of the draft constitutional treaty are: Part 1) defines the principles, objectives, and institutional provisions governing the European Union; Part 2) is the European Charter of Fundamental Rights; Part 3) is comprised of the provisions governing the policies and functioning of the Union; and Part 4) groups together the general and final provisions of the draft constitution (European Union, 2005). On July 9, 2004, the officials of the European Union issued a press release announcing that on the basis of the draft produced by the Convention, the Heads of State of Government of the 25 member countries reached an agreement on a constitutional Treaty for Europe. It was stated that the constitution will provide a "democratic, transparent, efficient Europe for all our citizens, a Europe that is visible and active on the world stage" (European Union 2004). Each member country of the European Union will ratify the constitution according to its own constitutional provisions. As of June 2005, 9 countries have ratified the treaty (Austria, Germany, Greece, Hungary, Italy, Lithuania, Slovakia, Slovenia, \& Spain) and 2 countries (France and the Netherlands) have voted against the Treaty (BBC News, 2005). The "no" votes reflected concerns about the poor economy of the country, immigration, EU expansion, and the loss of national identity. The remaining member countries will vote (through referendum or parliament) on the constitution Treaty in the near future. All $25 \mathrm{EU}$ member countries must approve the constitution for it to become effective October 2006 (CNN.com, 2005).

\section{Schengen}

On June 14, 1985, in an effort to development an agreement about the free movement of persons within the European Union, 5 countries (France, Germany, Belgium, Luxembourg, and the Netherlands) signed an agreement to create a territory without borders. This became known as the Schengen area, named after the Luxembourg town where the agreement was signed. The Schengen area was expanded to 15 members by 1996 (the original 5 plus Austria, Denmark, Finland, Greece, Iceland, Italy, Norway, Portugal, Spain, and Sweden). Although Ireland and the United Kingdom are not part of the Schengen area, they may choose to join at a later date. The main measures 
include: the removal of checks at common borders, common rules for crossing external borders, coordination of surveillance of borders, rules for asylum seekers, separate lines at ports and air terminals for people traveling within the Schengen area from those arriving from countries outside the area, and the creation of the Schengen Information System (an automatic network). The Schengen Agreement has been incorporated into the EU legal and institutional framework (Europa, 2005). Taking an unusual stance, the Swiss voted on June 5, 2005, to join the Schengen area in 2007 even though Switzerland is not part of the 25-member European Union (Cage, 2005). The creation of the Schengen area makes it much easier for business travelers that are from member countries.

\section{EU's Neighbourhood Policy (ENP)}

Ten years ago, in an effort to encourage political reform and gain from the benefits of free trade, the EU began a move towards the development of a series of Association Agreements between the EU and North African and Middle Eastern countries. The process starts with negotiation between the EU and the targeted country, proceeds to the development of a country report, and finally a draft Action Plan is prepared. Currently the EU has prepared Country Reports for Morocco, Tunisia, Jordan, Israel, the Palestinian Authority, Ukraine, and Moldova and these countries have the requisite committees in place for agreements to proceed. Lebanon and Egypt have Association Agreements in place and will be integrated into the ENP. The plan is to eventually create a Mediterranean free trade zone (Europa, 2005; Gorvett, 2005). Some of the non-European Union countries are concerned that there will be greater benefits for the EU companies than for local domestic industries. For example, Algeria has many statedowned inefficient companies that will not compete well against European companies that enter the market or against European goods that are imported into the country.. Because of limited competition and poor banking and capital markets, it will be easier for large, well financed EU firms to enter Algeria and make a profit. This may jeopardize local firms, but foreign firms entering the market will also bring jobs. The United States is also competing in the area by signing Free Trade Agreements with Morocco and other Middle East, Gulf, and North African countries (Gorvett, 2005) which will make it easier for U.S. goods and companies to also enter these countries. This will increase competition among EU and US firms as they compete for the limited consumer funds available in these countries.

\section{THE FUTURE}

What events will occur in the European Union in the foreseeable future? How might current events affect the future of the EU?

It might be appropriate to first discuss the future enlargement of the EU. Four countries have been accepted into candidacy to become members of the EU. On April 25, 2005, Bulgaria signed the accession agreement and will join the EU in 2007. Bulgaria is already linking its currency to the euro and has taken steps to integrate itself into the EU. Romania is set to join the EU in 2007 but only if it meets reforms and promises agreed to during negotiations. If these are not met, accession may be postponed one year. Croatia has been accepted into candidacy for joining the EU, but negotiations have not yet begun due to numerous political issues. EU officials expect Croatia will join the EU in 2009. Turkey became a candidate for membership in 1999 and is expected to begin accession negotiations in October 2005 (European Union, 2005; Wikipedia, 2005). The Republic of Macedonia became an official candidate March 22, 2004, and is expected to be recommended for candidacy in November 2005. Bosnia is expected to be given a chance to join the EU by 2010 but if progress toward meeting EU criteria is slow membership may be postponed to 2014 . Serbia must deal with ethnic tensions, poverty and corruption and Montenegro must deal with ecological, justice and crime problems. Both are preparing to join the EU in 2012. Albania hopes to join the EU between 2010 and 2015 (Wikipedia, 2005). As the EU continues to enlarge and create a larger single market, businesses will have easier access to a growing number of countries. As new countries become members there will be low-cost labor available for labor intensive industries for a number of years in the future. This will reduce costs of production and because all firms are located in the single EU market, shipping costs will be low and goods will not be subject to tariffs. This may result in greater efficiencies for EU firms. 
Proposition 1: It is expected that the EU union will continue to enlarge to at least 33 members within the next 10 years. Additional growth may occur if EFTA countries, other European countries currently not members, microstates (Vatican, Andorra, Monaco, San Marino), and former soviet states are considered for membership.

By May 2005, the European Constitution has been ratified by 9 countries and rejected by 2 countries. It is expected that England will postpone any vote on the constitution until 2006 and the remaining 13 countries still need to go through the approval process (by vote or referendum). Government officials of the EU and the 25 member countries place great importance on the constitution and will continue to work on gaining support from all member countries. France and the Netherlands could vote on the constitution again at some time in the future. However, the two 'no' votes have created a great deal of discussion about the concerns of the constitution. Many feel that the constitution is too cumbersome and has created a too centralized bureaucracy (which the people refer to as "Brussels"). Even if the new constitution is not approved by all 25 members, the EU can continue to function on the basis of earlier treaties (Economist, 2005; Molchanov, 2005).

Proposition 2: There is limited expectation that the constitution, in its current form, will be approved by all member countries. The constitution needs to be re-written so that it is simpler and clearly defines the distribution of powers.

Although the EU allows free movement of labor, there are numerous obstacles to workers moving from one country to another that decreases excessive immigration into western European countries. As a result, companies are beginning to move from Western Europe to the new member countries in the east in order to take advantage of lower wages levels, lower business tax rates, and other incentives. The average wage in the Czech Republic is 3.90 euro per hour, 4.5 euro per hour in Poland, and 3.8 euro per hour in Hungary compared to 23.8 euro per hour in France, 27 euro per hour in German, 27.20 euro per hour in Austria, or 16 euro per hour in Ireland (Nemcova, 2004). For labor intensive industries the lower wages are a lure. Business taxes in the Czech Republic have been reduced from $24 \%$ to $7 \%$, Poland and Slovakia both offer a $19 \%$ business tax rates, Hungary's tax rate is below $20 \%$, and Latvia offers tax exemptions of $80 \%$ in special economic zones (Salzmann, 2004). Service and IT jobs are already moving east and it is expected that car production will increase in Slovakia while the number of call centers in the Czech Republic will increase in the next few years (Salzmann, 2004).

Nemcova (2004) has compared this situation to one faced by the U.S. when businesses moved part or all of their production to China, Asia, and Mexico in order to take advantage of China's entry into the WTO, NAFTA, or low wage rates in Asian countries. This shift in production was not accompanied by high unemployment rates in the U.S. because U.S. firms continued to create new jobs. In the EU situation, the large single market allows economic activity to stay within the EU rather than being removed to countries outside of the European Union.

Proposition 3: As a result of limited labor mobility, EU businesses will relocate to the ten new member countries to take advantage of lower labor costs.

Proposition 4: Western EU countries will change incentives and tax structures in order to retain businesses.

One goal of the European Union is to become a major political and economic entity in the global environment. However, enlargement of the EU will be costly as subsidies to eastern EU countries will be approximately $\$ 40$ billion between the years 2004 and 2006 (Dixon, 2005). It will be very costly for countries and business owners to implement the rules and directives of the EU. Many of the citizens in the new member countries earn average monthly incomes of $\$ 450$, substantially less than that earned by western European counterparts. In a study of GDP growth, productivity and other factors, Deutsche Bank predicts it will take Slovenia 10 years to catch up to the EU average and it could take Poland 40 years to reach average EU living standards (Dixon, 2005). It is likely that over the next 15 years the EU will make slow but steady progress toward integration (Dixon, 2005). It would be expected that much of the EU's energies will be focused internally rather than externally. In addition, there has been little cohesion among EU government officials in their views of recent political issues (one example is the war in Iraq). 
Proposition 5: The European Union, as a single force, will have a limited role in world political issues but a greater role in business \& economic issues as the number of potential consumers and workers grows and the business climate remains conducive to foreign firms.

Many people and government officials throughout Europe held great hopes for the euro when it was launched in 1999. It was predicted that the euro would become strong currency in the world currency markets, would bring many benefits to businesses and citizens in the euro area, would create stability, and would compete with the U.S. dollar as a reserve currency. By 2005, we find there are some economic problems in Europe and the euro-area many of which are blamed on the euro. The Economist.com (2005) reports that: Italy is in its second recession in two years; Portugal, Germany, France, and Italy have increasing deficits; Germany is experiencing slow growth rates and doubledigit unemployment; and the European Central Bank has left interest rates at 2\% for the past two years. With the euro's appreciation against the dollar, European goods are becoming more expensive for U.S. consumers to purchase which has resulted in slowing exports. With the divergent business cycles, heterogeneous economic environments, and limited mobility of labor, it is suggested the current policies in place in the European Union may be insufficient to deal with the problems (Economist.com June 2005).

Proposition 6: The euro will not take its expected place as a strong currency in the world currency market within the foreseeable future. Continued economic problems will continue in EU countries and monetary actions taken by the European Central Bank will have limited results.

\section{CONCLUSION}

This paper has briefly reviewed the recent history and development of the European Union, discussed current events and their potential implications for businesses, and looked at the future of the EU and set forth propositions about what might be expected in the EU.

For businesses, the allure of a single market with a common currency, common trade policies, a large consumer market, and a low cost labor market will attract them to the European Union. As the European Union becomes more integrated in the next few years it will be even easier and more attractive to international firms.

\section{REFERENCES}

1. Ambler, M., Jone, V., Gacek, P., Stringa, G., and Horvath, M. (2000). The strategic impact of European Union enlargement, The Business View. PriceWaterhouseCoopers.

2. Batterson, R. (May 4, 2004). European Union enlargement to 25 members may someday challenge US as a single superpower. Washing University in St. Louis [On-line] Available at: http://news-info.wustl.edu/news

3. BBC News (June 1, 2005). Dutch vote on Europe constitution. BBC News. [On-line] Available at: http://newsvote.bbc.co.uk

4. Cage, S. (June 6, 2005). Swiss approve passport-free zone, give EU a boost. The Rocky Mountain News, pg. $37 \mathrm{~A}$

5. CNN.com (June 1, 2005). Dutch reject EU constitution. www.CNN.com [On-line] Available at: www.cnn.com/205/WORLD/europe

6. Dixon, P. (2005). The Future of the European Union. [On-line] Available at: www.globalchange.com/ futureerurope

7. Economist. (April 30, 2005). That damned, elusive constitution. The Economist. 375, 84 24, pg. 11.

8. Economist.com (June 6, 2005). Can this union be saved? [On-line] Available at: www.economist.com

9. Encarta (2004). European Union. [On-line] Available at: http://encarta.msn.com

10. Europa (2005). Europa website [On-line] Available at: www.europa.eu.int

11. European Union (2005). European Union website [On-line] Available at: www.eurunion.org

12. Financial Times (May 9, 2004). Economic summit - debate on Europe's future. Financial Times

13. Gorvett, J. (May 2005). EU ups the ante in Neighborhood expansion. The Middle East.

14. Hill, C.W.L. (2004). Global Business Today, McGraw-Hill/Irwin: New York.

15. McGill, A. (May 6, 2004). Report highlights threat to jobs of enlarged EU. Financial Times 
16. Molchanov, P. (June 1, 2005). Where next for the European Dis-Union? The National Business Review [Online] Available at: www.nbr.co.nz

17. Nemcova, I. (Summer 2004). EU growing pains. The Czechs in Europe.

18. OECD (2005). Organization for Economic Co-operation and Development website. [On-line] Available at: WWW.oecd.org

19. OECD Observer (April 30, 2004). Migration and EU enlargement. [On-line] Available at: Www.oecdobserve.org

20. Saltzmann, M. (April 20, 2004). The social consequences of European Union expansion. World Socialist Web Site. [On-line] Available at: www.wsws.org.

21. Wikipedia (2005). Enlargement of the European Union. [On-line] Available at: www.wikipedia.org 